\title{
Left Main Coronary Artery Bifurcation
}

National Cancer Institute

\section{Source}

National Cancer Institute. Left Main Coronary Artery Bifurcation. NCI Thesaurus. Code C116174.

The portion of the distal end of the left main coronary artery that branches into the left anterior descending artery and the left circumflex artery. 